\title{
A Novel View of Human Helicobacter pylori Infections: Interplay between Microbiota and Beta-Defensins
}

\author{
Raffaela Pero ${ }^{1,2, *(\mathbb{D}}$, Mariarita Brancaccio ${ }^{3}$, Sonia Laneri ${ }^{4}$, Margherita-Gabriella De Biasi ${ }^{4}$, \\ Barbara Lombardo 1,5 (D) and Olga Scudiero 1,2,5,* \\ 1 Dipartimento di Medicina Molecolare e Biotecnologie Mediche, Università degli Studi di Napoli \\ "Federico II", 80131 Napoli, Italy; barbara.lombardo@unina.it \\ 2 Task Force sugli Studi del Microbioma, Università degli Studi di Napoli “Federico II", 80131 Napoli, Italy \\ 3 Department of Biology and Evolution of Marine Organisms, Stazione Zoologica Anton Dohrn, 80121 Napoli, \\ Italy; mariarita.brancaccio@szn.it \\ 4 Dipartimento di Farmacia, Università degli Studi di Napoli “Federico II", Via Montesano 49, 80131 Napoli, \\ Italy; slaneri@unina.it (S.L.); margherita.debiasi@unina.it (M.-G.D.B.) \\ 5 CEINGE-Biotecnologie Avanzate Scarl, Via G. Salvatore 486, 80145 Napoli, Italy \\ * Correspondence: pero@unina.it (R.P.); olga.scudiero@unina.it (O.S.); Tel.: +39-081-7704795 (R.P.); \\ +39-081-3737819 (O.S.)
}

Received: 18 May 2019; Accepted: 13 June 2019; Published: 18 June 2019

\begin{abstract}
The gut microbiota is significantly involved in the preservation of the immune system of the host, protecting it against the pathogenic bacteria of the stomach. The correlation between gut microbiota and the host response supports human gastric homeostasis. Gut microbes may be shifted in Helicobacter pylori $(\mathrm{Hp})$-infected individuals to advance gastric inflammation and distinguished diseases. Particularly interesting is the establishment of cooperation between gut microbiota and antimicrobial peptides (AMPs) of the host in the gastrointestinal tract. AMPs have great importance in the innate immune reactions to $\mathrm{Hp}$ and participate in conservative co-evolution with an intricate microbiome. $\beta$-Defensins, a class of short, cationic, arginine-rich proteins belonging to the AMP group, are produced by epithelial and immunological cells. Their expression is enhanced during $\mathrm{Hp}$ infection. In this review, we discuss the impact of the gut microbiome on the host response, with particular regard to $\beta$-defensins in $H p$-associated infections. In microbial infections, mostly in precancerous lesions induced by $\mathrm{Hp}$ infection, these modifications could lead to different outcomes.
\end{abstract}

Keywords: Helicobacter pylori; defensins; microbiome; infections

\section{Introduction}

Helicobacter pylori $(\mathrm{Hp})$ infections are related to the onset of various gut diseases, such as gastritis, gastric cancer, and mucosa-associated lymphoid tissue lymphoma (MALT) [1-3]. Different studies have been developed to understand how $\mathrm{Hp}$ can cause local and systemic effects on the human host. An important mechanism involved in these effects is probably injury to the host as a result of chronic inflammation [4]. Recently, various studies have started to concentrate on the impact of $H p$ and its metabolism on the gut microbiome [5-8]. This rising area could partly elucidate the large heterogeneity of results that are, at present, due to the infection of $H p$ in the host.

This review describes the effects of the gastrointestinal microbiome on the host response, with particular regard to the role of $\beta$-defensins in $H p$-related infections. 


\section{Human $H p$ Infections}

$H p$ infection is acquired throughout babyhood through intrafamilial transmission, and in many cases, it proceeds, unless removed by antibiotic treatment [9]. Chronic infection by $\mathrm{Hp}$ results in mucosal gastric inflammation, which is devoid of clinical symptoms in most infected subjects. Only a minority of infected people develop severe gastroduodenal diseases [10]. Among these infected individuals, about $10 \%$ develops ulcers, $1-3 \%$ develop gastric carcinoma, and fewer than $0.1 \%$ develop gastric MALT (Associated Lymphoid Tissue Lymphoma).

Intestinal epithelial adenocarcinoma is the most common type of $\mathrm{Hp}$-induced gastric cancer. This type of cancer begins with passage from the normal mucous membrane to chronic gastritis. Progression through a series of distinct histologic steps from atrophic gastritis is succeeded by enteral metaplasia, resulting in dysplasia and adenocarcinoma [11,12].

Several other factors are involved in the cancerogenesis process such as epigenetic $[13,14]$ and inflammatory [15] alterations triggered by $\mathrm{Hp}$ in the host cell genome. These represent critical hallmarks of gastric cancer.

Gastritis generally consists of inflammation of the mucosal lining of the stomach, which can subsequently lead to the development of ulcers. The ruling etiology of gastritis worldwide is thought to be $H p$ infection, and $H p$ infection also augments the risk of non-cardia gastric cancer by six to eightfold $[16,17]$.

Gastritis induced by $\mathrm{Hp}$ can affect antral or corpus gastric function. In antrum gastritis, $\mathrm{Hp}$ provokes an increase in gastrin secretion which leads to greater production of gastric acid, which renders subjects more susceptible to peptic ulcers, but less predisposed to gastric cancer (GC). In corpus gastritis, $\mathrm{Hp}$ inhibits the production of acid via inflammation, which causes a gradual leak of gastric glands and finally, leads to atrophic gastritis [16].

The decreased secretion of gastric acid promotes the persistence of bacteria usually killed by the adverse environment of the stomach.

The way in which the altered microbiota interacts with $H p$ to prompt tumorigenesis is not completely known. Probably, these microorganisms can transform nitrogen compounds into carcinogenic N-nitroso compounds.

For example, Lactobacillus, Escherichia coli, and Staphylococcus, can produce N-nitroso compounds $[18,19]$. On the contrary, Streptococcus, Prevotella, and Neisseria commensals are related to a poor risk of development of gastric cancer $[20,21]$ (Table 1).

Table 1. Helicobacter pylori $(\mathrm{Hp})$ and human gastric microbiota.

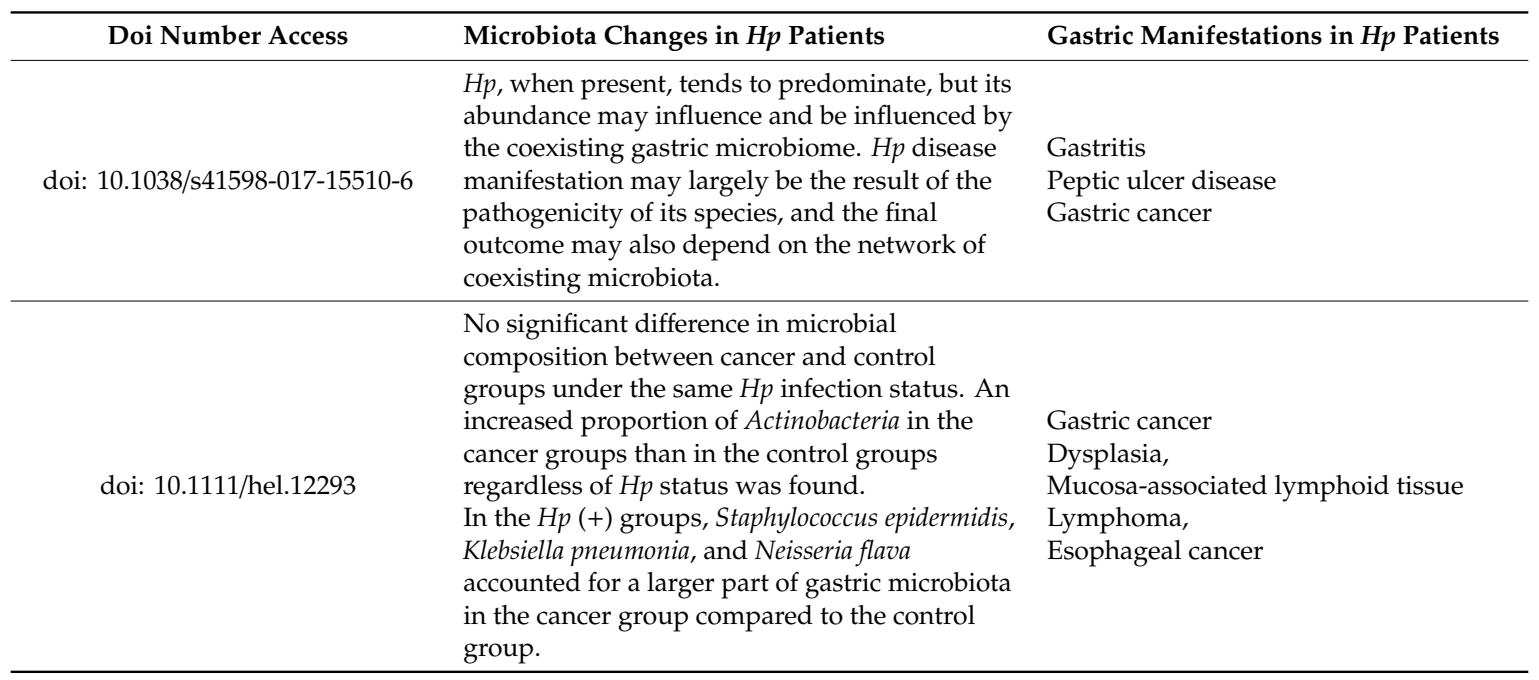


Table 1. Cont.

\begin{tabular}{|c|c|c|}
\hline Doi Number Access & Microbiota Changes in $\mathrm{Hp}$ Patients & Gastric Manifestations in $H p$ Patients \\
\hline $\begin{array}{c}\text { doi: } \\
\text { 10.1097/INF.0000000000001383. }\end{array}$ & $\begin{array}{l}\text { Bacterial richness and diversity of } \mathrm{Hp} \text {-positive } \\
\text { specimens were lower than those of negative } \\
\text { specimens. } \\
H p \text { subjects had a higher relative abundance of } \\
\text { the Helicobacter genus than } \mathrm{H} p \text {-negative } \\
\text { subjects. }\end{array}$ & Dyspeptic symptoms \\
\hline $\begin{array}{c}\text { doi: } \\
\text { 10.1371/journal.pone.0007985 }\end{array}$ & $\begin{array}{l}\text { Significantly higher abundance of the Firmicutes } \\
\text { and Streptococcus genus was observed in } \\
\text { patients with antral gastritis. }\end{array}$ & Dyspeptic symptoms \\
\hline doi: 10.1038/mi.2016.131 & $\begin{array}{l}\text { The gastric microbiota of } \mathrm{Hp} \text {-infected children } \\
\text { was distinct from that of non infected children } \\
\text { in terms of the abundance of multiple bacterial } \\
\text { classes, orders, families, and genera. }\end{array}$ & $\begin{array}{l}\text { Peptic disease: } \\
\text { Dyspepsia } \\
\text { Recurrent abdominal discomfort } \\
\text { Pain }\end{array}$ \\
\hline $\begin{array}{c}\text { doi: } \\
\text { 10.1056/NEJM199607253350404 }\end{array}$ & $\begin{array}{l}\text { Autoimmune and } \mathrm{Hp} \text {-induced atrophic gastritis } \\
\text { were associated with different gastric profiles. } \\
\text { Proton pump inhibitor (PPI)-treated patients } \\
\text { showed relatively few alterations in the gastric } \\
\text { microbiota compared to healthy subjects. }\end{array}$ & $\begin{array}{l}\text { Autoimmune atrophic gastritis } \\
\text { Hp-induced atrophic gastritis } \\
\text { Hp gastritis }\end{array}$ \\
\hline doi: 10.3748/wjg.v18.i11.1257 & $\begin{array}{l}\text { High prevalence of non- } \mathrm{Hp} \text { bacteria dominated } \\
\text { by some species. }\end{array}$ & $\begin{array}{l}\text { Gastritis } \\
\text { Gastric ulcer } \\
\text { Duodenal ulcer } \\
\text { Reflux esophagitis } \\
\text { nonulcer dyspepsia }\end{array}$ \\
\hline
\end{tabular}

\section{Control Human Gut Microbiome}

The microbiome represents the whole microbial community present in the body of a defined host. In humans, the microbiome contains bacteria, viruses, fungi, and Archeae [22-24]. The microbiome mutates profoundly among subjects, and colonization by particular microbes could confer protection or susceptibility to disease, especially in chronic infections related to $H p$ [25].

The majority of the human gut microbiome is represented by anaerobic bacteria, such as Bacteroidetes, Firmicutes or Proteobacteria, while a minor proportion $(<1 \%$ in frequency) belong to other phyla, such as Actinobacteriae, Acidobacteriae, Verrumicrobiae, or Fusobacteriae. Moreover, inside a specific level of the GIT (gastrointestinal tract), we can also observe a difference in bacterial composition (Figure 1).

To this level-specific variation, diversity between the epithelium and the intestinal lumen is added.

This diversity is caused by the production of mucus by the goblet cells, limiting the capability to adhere and invade the specialized bacteria [26-28]. 


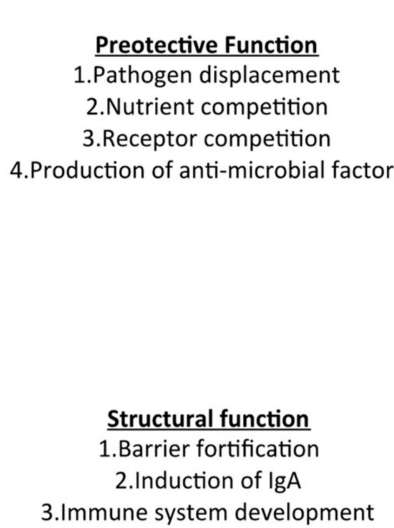

Figure 1. Role of intestinal microbiota.

The glycosylated proteins of the mucus represent a nutrient tank for bacteria such as Clostridium, Lactobacillus, or Enterocuccus, which is used before accessing the intestinal cells [29]. Differences have been shown between diversity and compositions of biopsies or stools [30].

Also, in the microbiome of the gastric corpus, the species richness is higher than in the antrum; however, no differences have been found regarding diversity.

Furthermore, in the gastric corpus, a more diversified microbiome is present in $H p$-negative individuals compared to $\mathrm{Hp}$-positive individuals. An analysis of beta diversity showed that the status of $H p$ infection is more significant than the antrum or corpus [31].

In addition, an analysis of the gastric microbiota showed comparable settlement in control individuals from diverse cultural groups and different geographic backgrounds [32].

\section{Hp and the Gut Microbiome}

$\mathrm{Hp}$ can cause alterations in the host by modifying the gut microbiome. A growing number of studies is reporting greater ecosystem diversity in the gastrointestinal tract and associating the presence of $H p$ with variations within the structure of the microbiome [33-39].

The most common genera in healthy and negative- $H p$ gastritis subjects are Neisseria, Prevotella Porphyromonas, and Haemophilus [29]. Additionally, Lactobacillus, Streptococcus, and Propionibacterium represent prevailing genera in normal people [36].

At the phylum level, the presence of $\mathrm{Hp}$ has no result on the diversity or uniformity of the gastrointestinal microbiome [35].

However, the presence of $\mathrm{Hp}$ is able to induce drastic alterations in the variety of gut microbiota $[6,39,40]$.

Modifications due to the presence of $\mathrm{Hp}$ concern the raise in the relative richness of Acidobacteria, Spirochetes, and Proteobacteria, and the reduction of Firmicutes, Actinobacteria, and Bacteroidetes [39]. Besides, greater amounts of Firmicutes, Actinobacteria and Bacteroidetes have been reported in people with low $H p$ levels. Such divergences could be due to variations between subjects, as the gut microbiome appears to be responsive to external influences, such as lifestyle and nutrition [41,42].

The time period for acquiring $\mathrm{Hp}$ infection is another aspect to consider in the divergence reported for the microbiome variations associated with $\mathrm{Hp}$. Modifications in the variety and constitution of the community have been ascertained in the guts of children and even in relation to adults, despite the $\mathrm{Hp}$ status [43].

Therefore, the premature acquisition of bacteria probably forms the structure of the microbiome through the induction of native changes in the gastric habitat. A mechanism involved in these effects could be the output of ammonia and bicarbonate, starting by urea. Ammonia and bicarbonate might function as substrates for alternative bacteria, as well as changing the $\mathrm{pH}$ of the stomach, which promotes the settlement of alternative species, such as nitrogen-reducing microbes [44-47]. 
The effect of $H p$ on acid secretion looks to depend upon the type of $H p$-induced gastritis. The production of gastric acid increases in antral gastritis and decreases in that of the body. Therefore, changes to the microbiome could be problematic in each case. Hyperchlorhydria will increase the microbial variety in the gastric tract and has been related to the development of gastric carcinogenesis. In addition, the consistency of gastric mucus decreases with an increasing $p H$, making it more accessible to alternative bacteria to colonize epithelial tissue. Finally, $\mathrm{Hp}$ may directly modify the mucosal barrier by altering the expression of gastric mucins [48-54].

These ambient alterations in the gut may affect the natal microbiome [55]. Additionally, the immune reaction driven by $\mathrm{Hp}$ may alter the native microbiome further, as microorganism populations exist at a lot of distal sites in the human organism.

In Mongolian gerbils, chronic $H p$ infection causes degenerative alterations. These alterations occur with variation in the expression of genes linked to immunity in both the stomach and respiratory organs [56]. Perhaps, premature settlement changes could lead to alterations in the hollow microenvironment, while late ones could be conducted by an additional shift in the inflammatory and immune response primed by $H p$ [57]. It is possible that $H p$ may have an effect on mucosal diseases in remote sites through its impact on immune cells that move through the body's circulation. Hp even provokes a change in the immune reaction through the elicitation of Treg cells (regulatory T cells) with VacA (vacuolating cytotoxin A) and GGT (gamma-glutamyl transpeptidase) intermediates [58,59]. Treg cell reactions are critical for the discrimination between self and foreign antigens, i.e., immune tolerance. This discovery may explain the persistence of $H p$ in the stomach and could also help suppress gastric inflammation, which may justify a reduction in the severity of gastric disease in $H p$-positive children related to $H p$-positive adults [42]. The infection by $H p$ in the stomach has been correlated with modifications of the gastrointestinal microbiome at alternative places in the organism. Reasonably, alternative members of gut microbiota can also contribute to changes discovered after $\mathrm{Hp}$ infection by the host. In fact, there is a direct interaction between $\mathrm{Hp}$ and Streptococcus mitis that causes the passage of $H p$ from a spiral to coccoid shape that is most refractory to stressful environments [60]. In addition, antimicrobial molecules made by Lactobacillus spp. are active against $H p$ strains [61-63]. Therefore, there is a two-way communication and modulation between $\mathrm{Hp}$ and other constituents of the microbiota and, consequently, the set of these influences will be reflected by the health of the host [64]. In this way, changes in the microbiome triggered by the first acquisition of $H p$ could also confirm the immunological status of the host and, as a result, the occurrence of many general diseases. This is relevant, since once the microbiota is altered by treatment with antibiotics, $\mathrm{Hp}$-induced inflammation is reduced [42].

\section{Gut Microbiota in $H p$ Infections}

The host's metabolism is affected by $H p$ and gut microbiota. The impact of $H p$ infection on modifications to the gastro-intestinal microbiota has been examined in animals and humans [65-67].

In rhesus macaques, there are no important changes in the richness of non-Helicobacter taxa in the stomach pre-and post-infection with $H p$ [65]. Other studies have shown increases in Staphylococcus aureus and Enterococcus spp. in the gastrointestinal tract and a down-shift of Lactobacillus spp. in the gut of Mongolian gerbils infected with $H p$ [66]. Similarly, mice infected with immunopathological $H p$ B8 can augment the intestinal charges of E. coli in the cecum and Bacteroides/Prevotella spp. in the colon [60].

$\mathrm{Hp}$ seems to be a crucial constituent of the gut microbiota and, when present, has the highest relative abundance [35]. A decrease in Proteobacteria and an augment in Firmicutes have been demonstrated in subjects with $\mathrm{Hp}$-positive antral gastritis related to $\mathrm{Hp}$-negative gastritis [38]. Similarly, an increase in Streptococcus and a reduction in Prevotella have been discovered in subjects with atrophic gastritis likened to control ones [32]. 
The predominance of non- $\mathrm{Hp}$ microbes was found to be greater in subjects with non-ulcerative dyspepsia than in those with peptic ulcers. Instead, the isolation of Streptococci and not of $\mathrm{Hp}$ has been correlated with the development of peptic ulcers $[68,69]$.

\section{Gut Microbiome Modifiers}

As well as $\mathrm{Hp}$ presence, the structure of the gut microbiota could be altered by diet, lifestyle, medication use, age, exercise, and genetic factors [68-74] (Figure 2).

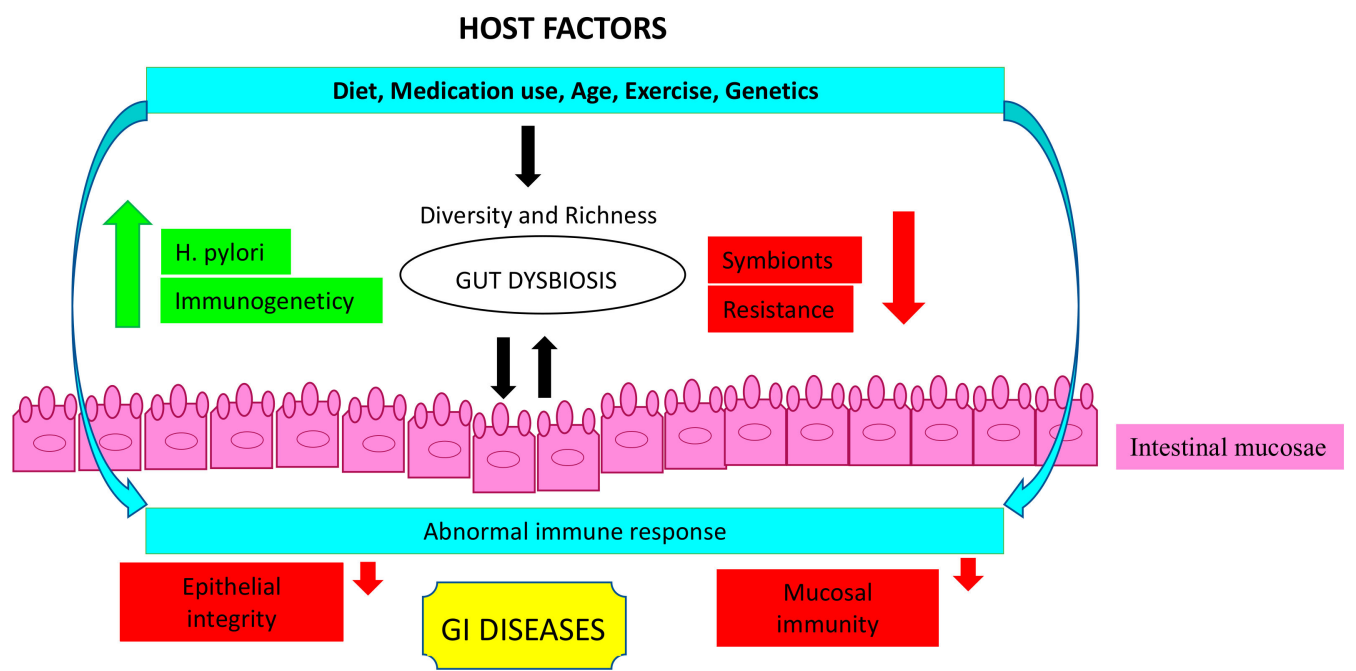

Figure 2. Gut microbiota modifiers. Host factors that modify the gut microbiota composition in the gastrointestinal diseases.

\subsection{Diet}

Dietary factors considerably change both the function and the composition of gut microbiota. A landmark study investigated the microbiota of Italian and countryside African children. Prominent exhaustion of Enterobacteriaceae and Firmicutes and, remarkably, more short chain fatty acids (SCFAs) were found to occur in African children.

Foods of animal origin were shown to promote the growth of bile-tolerant bacteria microorganisms, while the ability of Firmicutes to process the polysaccharides of vegetal foods was diminished. This study highlights a significative correlation between bile acids, saturated milk fats, and excessive proliferation of some proinflammatory microorganisms such as Bilophila wadsworthia [75-78], which is associated with chronic inflammatory diseases [76]. Substantial shifts in the microbial constitution of the intestines were observed during the change to a high fat diet (HFD) with a reduction in the phylum Bacteroidetes and increases in the phyla Firmicutes and Proteobacteria. Furthermore, the consumption of red meat was correlated not only with a poor grade of inflammation, but also with a particular microbiome in subjects with late adenoma and colorectal carcinoma (CRC) [77].

\subsection{Medication Use}

The proton pump inhibitor (PPI) produces a significant decrease in gastric $\mathrm{pH}$, and the constitution of the gut microbiota is more similar to the fecal one than that of the $\mathrm{H} 2$ antagonists and the untreated control [79]. Treatment with antibiotics induces modifications in the gastric microbiota and an imbalance between Bacteroidetes and Firmicutes. The diversity and abundance of these bacteria decrease during antibiotic treatments. The alterations of the microbiome depend on the type of antibiotic used, the dosage, the time of administration, the pharmacological action and the target bacteria. Antimicrobial results or modalities of functioning are crucial for the sorting of gut microbiota and are a reliable way of assessing the composition of microbial alterations during antibiotic treatment [80-82]. 


\subsection{Age}

With age, the microbiota diversity increases until it becomes a stable adult microbiota. Three bacterial phyla dominate the composition, Firmicutes, Bacteroidetes and Actinobacteria, which is influenced by genetic factors, diet, environment, lifestyle, and gut physiology.

In children, the gut microbiota composition and diversity are like those of adults by about three years of age $[83,84]$.

\subsection{Exercise}

In young children and adolescents, daily exercise increases gut microbial diversity with the enrichment of Firmicutes, such as Clostridiales, Roseburia, Lachnospiraceae, and Erysipelotrichaceae. These microbes generate SCFAs that can enhance the levels of tight junctions in the gastrointestinal tract to improve colon barrier solidity, reduce mucosa permeability, and inhibit inflammation triggered by cytokines $[84,85]$.

In athletes, higher alpha diversity of gut microorganisms has been demonstrated compared with high and low body mass index (BMI) controls. Indeed, this study showed that exercise elevates gut microbial diversity and protein depletion. Therefore, there is a beneficial impact of activity on the variations of gut microbiota, and the correlation between physical activity and microbiota diversity is probably related to the concomitant dietary extremes [86].

\subsection{Genetic Factors}

Genetic aspects of the host are able to affect the gastrointestinal microbiota and its metabolic phenotype.

Allele-specific single nucleotide polymorphisms (SNPs) are related to gut microbiota and are connected with illnesses such as obesity, Type 2 diabetes (T2D), and CRC [87].

In healthy individuals, some fecal bacterial taxa are heritable, and SNPs are associated with Faecalibacterium, Lachnospira, Rikenellaceae, and Eubacterium [88].

A gender variance in gut microbiota was also detected owing to differences in daily and social practices [89].

The microbial constitution of the stomach is also influenced by the presence, in the mucosa, of $\mathrm{ABH}$ antigen, whose production depends on the FUT2 (Fucosyltransferase 2) gene. The $\mathrm{ABH}$ antigen is one of the most famous polymorphisms in the field of blood antigens in body excretions. On red blood cells, they are in the form of fat-soluble glycolipids, and in secretions, they occur as water-soluble glycoproteins.

Mutations in the FUT2 gene render individuals unable to secrete the ABH antigen. In these individuals, Bifidobacterial variance and abundance, particularly B. catenulatum/pseudocatenulatum, B. adolescentis, and B. bifidum, decreases [90].

A very recent study suggested that the protein P1454 is released by $\mathrm{Hp}$ in infected patients, and it drives Th1 (T cell helper 1) and Th17 (T cell helper 17) inflammatory responses during chronic $H p$ infection and in patients with distal adenocarcinoma [91].

Also, ambient factors predominate above genetics in forming the gut microbiota. In fact, around $20 \%$ of the interpersonal variability of the microbiome is related to factors such as lifestyle, anthropometric criteria, diet, and drugs (Figure 3). 


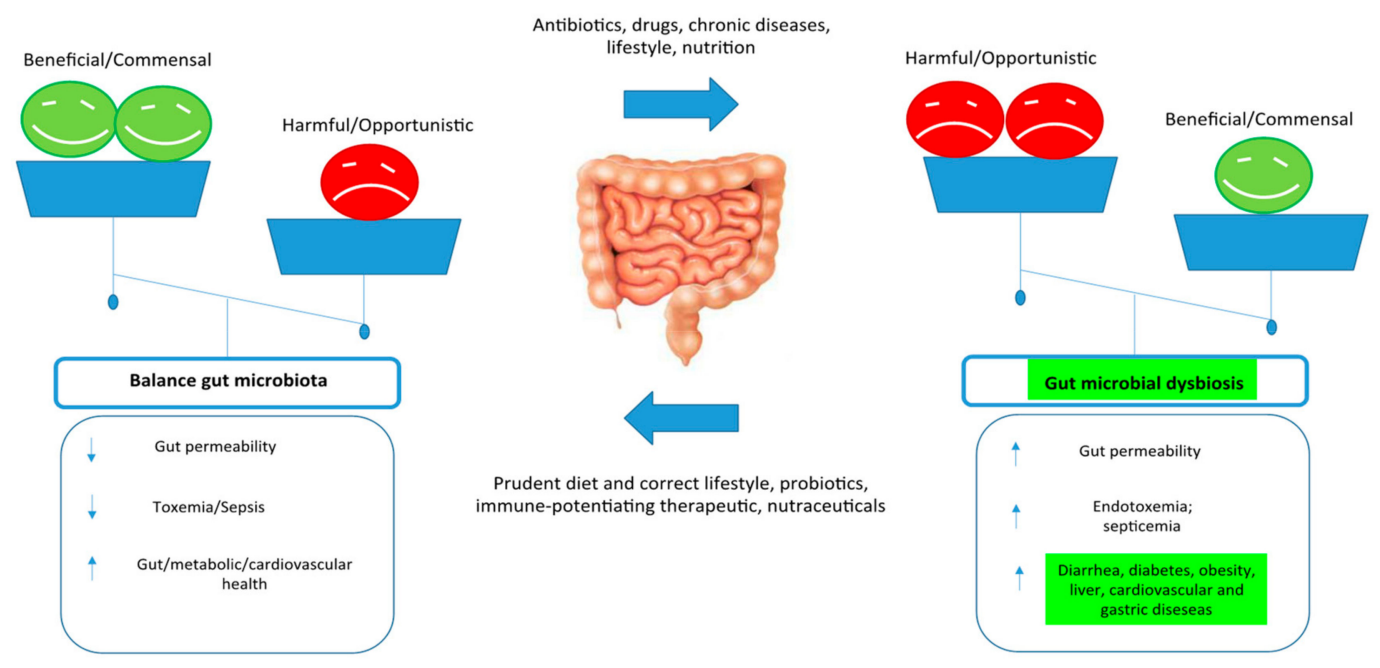

Figure 3. Importance of balanced nutrition and gut microbiota, and consequences of gut dysbiosisis.

In contrast, in twins, only a small percentage (about $2-8 \%$ ) of the microbiome taxa is heritable [92].

\section{Beta-Defensins and Microbiota in $\mathrm{Hp}$ Infections}

\subsection{Human Defensins: Classification}

Defensins are short proteins belonging to the mammalian antimicrobial peptides (AMPs) family. These proteins have a large range of antimicrobial activity against bacterial cells, viruses, fungi, and protozoa [93-96].

The primary sequences of defensin consist of preserved cysteine residues, which form disulfide bridges that give rise to a three-dimensional conformation preserved within family members [92]. Defensins fall into three main groups, called $\alpha, \beta$, and $\theta$.

$\alpha$-defensins, including human $\alpha$-defensin 5 (HD-5) and 6 (HD-6) in humans, are mainly expressed in the Paneth cells of the small intestine [94].

In contrast, $\beta$-defensins are secreted in the small and large intestines [97]. The expression of $\theta$-defensins is limited to rhesus macaques [98].

The structural features of defensins provide information on their mechanism of action against bacteria. The HD-5 has a three-dimensional dimeric structure, a basket shape conformation, and a typical amphipathic disposition [99]. HD-6 dimers are able to self-associate, creating higher-order oligomers and building lengthy fibers [100]. $\alpha$-defensins can give rise to membrane pores or canals that lead to ions [101].

Because $\alpha$-defensins are fixed by three disulfide bonds which confer conformational rigidity, the development of a secondary structure based on the lipid bond is limited [102].

The antimicrobial activity of some defensins is also based on mechanisms different from a straight microbial kill. For example, HD-6 oligomerizes and forms lengthy fibers that serve to trap microbes on the intestinal surface, preventing their translocation through the epithelial barrier.

However, in a reducing environment, the disulfide bonds of HD- 6 are reduced, and antimicrobial activity occurs, causing the destruction of the cell wall [103]. Probably, both mechanisms explain the activity of HD-6 against in vivo bacteria. The expression of $\alpha$-defensins is controlled by the WNT pathway transcription factor TCF4, but their production is independent of microbial signals [104].

Some $\beta$-defensins are expressed separately to the microbiota, while other members, including $\beta$-defensin 2 (HBD-2), exhibit greater expression in the presence of bacteria [97].

AMPs are induced only as required, thus reducing their probability of unnecessarily altering the composition of the intestinal microbiota or compromising its beneficial contributions. 
The harmful actions of AMPs are usually inhibited during storage within vesicles of secretion; otherwise, they may also damage the membranes of host cells [105].

$\alpha$-defensins are saved as inactive pro-peptides within the secretory granules of epithelial cells. Human pro- $\alpha$-defensins undergo proteolysis to generate fully developed proteins with bactericidal activity [106].

Filamentation represents yet another mechanism that regulates AMP action. AMPs are also required to limit the entrance of the microbiota to host cells. The intestinal surface is clothed by mucus that behaves like a physical barricade against lumen bacteria and concentrates AMPs near the surface [107].

In the gastrointestinal tract, and probably somewhere else, HBD-1 expression is also relatively controlled by the receptor activated by the nuclear receptor peroxisome proliferator gamma (PPAR $\gamma$ ), a crucial factor for gut homeostasis in response to inflammation, diet, and the microbiota [108].

PPARs are elements of the nuclear receptor superfamily and include three elements: PPAR $\alpha$, $\operatorname{PPAR} \beta / \delta$, and PPAR $\gamma$, also known as nuclear receptor subfamily 1 , group $C$, and members (NR1C)1, 2 , and $3[109,110]$.

Although there is a spatial barrier between the PPARs and tissues of our body, they form interfaces with each other. The metabolites generated inside the microbiota are assimilated by inflammatory and intestinal cells. These metabolites are carried to various organs through the systemic circulation, where they function as PPAR ligands. Once activated, PPARs modulate: (i) the intestine, (ii) the body's immune response, and (iii) carbohydrate and fat metabolism. For example, sodium colitis mice dextran sulfate treated with Lactobacillus paracasei B21060 upregulates both PPAR $\gamma$ and $\beta$-defensin. This enhancement is linked to the renovation of intestinal stability, suggesting that the microbiota modulate PPAR $\gamma$ while preserving intestinal homeostasis [111].

Additionally, PPARs activate HBD-1 mediated immunity in Crohn's disease, which constitutes another intestinal anti-inflammatory mechanism [108].

\subsection{Beta-Defensins in Hp Infections}

Defensins have an essential role in the onset of $\mathrm{Hp}$-infections. The distribution of the resulting gastritis is influenced by genetic factors, bacterial virulence, the age of infection, and the environment [112]. Hp infection drives a more important increase in HBD-2 than non-Hp gastritis [113]. Furthermore, $\mathrm{Hp}$ induces endogenous HBD-2 expression from gastric epithelial cells, and this improvement is regulated by the recognition receptor NOD1 (Nucleotide Binding Ligand Domain 1) [114]. In $\mathrm{Hp}$-induced gastritis, there are essential increases in HBD-1 and HBD-2 expression with respect to the control. The same increases in HBD1 and HBD-2 expression were detected during bacterial inflammation, suggesting an essential role of innate host defense against potentially injurious stimuli in the stomach [115]. Moreover, subjects with Hp-infected gastritis overexpresses HBD-2 mRNA, while those who are Hp-negative show only weak HBD-2 expression, indicating that the presence of $H p$ enhances HBD-2 expression in the gut. Besides, there is a marked diversity in HBD-2 expression in the gastric corpus of $H p$ individuals related to those who are $H p$-negative. In addition, HBD-1 is expressed unevenly, further indicating the failure of transcriptional regulators for pro-inflammatory markers in the HBD-1 gene [116].

HBD3 is expressed regularly, despite colonization of $\mathrm{Hp}$. Furthermore, HBD-3 is mainly expressed in the gut in the presence of $H p$, but not in the absence of it [117].

HBD-4 is poorly expressed in gastric cells and is mostly up-regulated in $\mathrm{Hp}$ and non- $\mathrm{Hp}$ gastritis. The $c a g A^{\dagger}$ (cytotoxin-associated gene) $\mathrm{Hp}$ strain results in significant expression of HBD-4 compared with the cag $A^{-}$strain. The pathway of toll-like receptors (TLRs) is not related to modifications in HBD-4 expression; however, p38 mitogen-activated protein kinase plays an essential role [118]. This research shows that $H p$ modulates the expression of $\beta$-defensins, which are critical regulators of the innate immune response in the host. Antimicrobial proteins are capable of changing the structure of gut microbiota during host infection. 
There is a robust correlation between $H p$ infection and peptic ulcers. Peptic ulcers represent gaps in the covering of the gastrointestinal mucosa that are usually produced by $\mathrm{Hp}$ and non-steroidal anti-inflammatory medicaments. A peptic ulcer is linked with significative mortality and complications such as bleeding and perforation. Individuals with a peptic ulcer have less HBD-1 and greater HBD-2 expression than those with a healthy stomach, and this model is particularly marked in individuals infected with Hp. Probably, this increased expression of HBD-2 constitutes a protective reaction by the gastric epithelium to restrict the infection [119].

\subsection{Beta-Defensins and Microbiota}

AMPs have a notable impact on the constitution of the gastrointestinal microbiota. The power to elude them has given some pathogens selective supremacy $[120,121]$. This is especially evident in the case of $H p$, which uses the cholesterol of the host to obtain resistance against catelicidin-37 (LL-37) [122].

Furthermore, even if the gastritis that promotes $\mathrm{Hp}$ induces HBD-2, it seems to selectively inhibit another $\beta$-defensin, HBD-3 [123].

$\beta$-defensins participate in the development of generic biochemical characteristics such as a positive charge and disulfide bonds, which are essential for antibacterial activity [124]. Although these characteristics are rather comparable among the respective HBDs, there may be large variations in their efficacy and type of activity. A suggestive example is HBD-1, which, in vitro, has only a faint antimicrobial function related to HBD-2 or other defensins. The justification for this loss of capacity is that the rather intense antimicrobial activity of HBD-1 is influenced by biochemical activation in reducing conditions [115].

Previous studies have provided evidence that the gastrointestinal microbiota modulates the secretion of defensins. The pre-incubation of Caco-2 cells with live E. faecium was found to remarkably decrease the internalization of $S$. typhimurium, whereas pretreatment with thermally killed E. faecium did not affect the internalization of pathogens [125]. Moreover, only live gut microbiota can actively upregulate the levels of HBD-2 [126-128]. In addition, a supernatant of $H p$ bacteria was not sufficient to enhance HBD-2 in MKN45 cells, suggesting a strain-dependent mechanism, and for certain bacteria, a straight interplay between bacteria is essential for the expression of AMPs. Moreover, genetical aspects are involved in the modulation of $\beta$-defensins, because it was found that only cag pathogenicity island (PAI)-positive Hp strains are capable of inducing HBD-2 expression [125]. The redox state of some defensins could be involved in the modulation of the constitution of the microbiota on the surface of the epithelium and, probably, in precluding the translocation of the microorganisms. In particular, the non-pathogenic E. coli Nissle 1917 strain evokes the most pronounced expression of $\beta$-defensin in vitro [126,128]. It is interesting to note that different mutants of E. coli Nissle 1917 are major stimulating factors for the secretion of $\beta$-defensin [126]. Furthermore, NF-kB mediates the expression of $\beta$-defensin induced by E. coli Nissle 1917 via MAPK/AP-1 pathways [127] (Figure 4).

However, other data are necessary to validate whether gut microbiota can enhance $\beta$-defensin expression to decrease bacteria colonization and regulate homeostasis of the intestine. Some molecules produced by the intestinal microbiota, including ligands of aryl hydrocarbon (AHR) and butyrate, have been shown to promote the secretion of Interleukin 22 (IL-22) by pancreatic lymphoid cells (ILCs), which consequently upregulates the secretion of $\beta$-defensin 14 (BD14) by endocrine cells. Thus, dysbiosis of the microbiota and the weak affinity of the aryl hydrocarbon receptor (AHR) allele seem to explain the deficient secretion of mouse $\beta$-defensin 14 (mBD14) in the pancreases of NOD mice [125]. Since only live gut microbiota is able to induce the expression of $\beta$-defensins, most likely a specified microbiota metabolic function, the closure of paths for the expression of AHR ligands may have the capability to modulate the flow of $\beta$-defensins (Figure 5). 


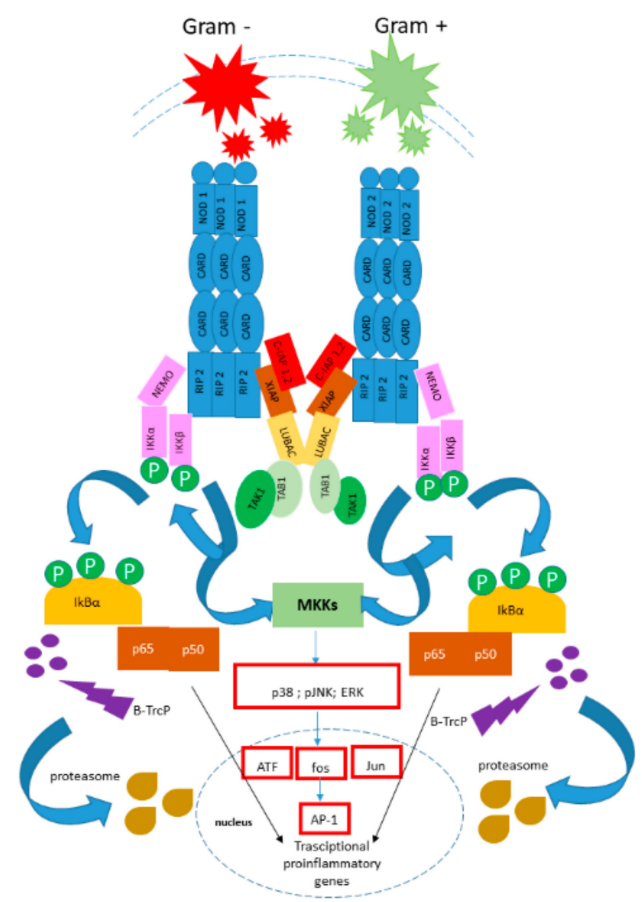

Figure 4. NF- $\mathrm{kB}$ and AP-1 pathways. These ligands bind to NOD1 or NOD2 through the LRR domain of these molecules. This interaction initiates the activation of NOD1 and NOD2 due to the induction of a complex conformational change that results in protein oligomerization and further interaction with downstream effectors. NOD1 or NOD2 assembly recruits RIP2 through CARD-CARD interactions, resulting in RIP2 ubiquitination by IAPs and recruitment of the LUBAC complex by XIAP, with further binding of the TAB1/TAK1 complex. It is believed that TAK1 gets activated through autophosphorylation and stimulates the downstream IKK complex, including Lys63-linked polyubiquitination of NEMO (IKK $\gamma)$, the regulatory subunit of the IKK complex, which also consists of the catalytic subunits IKK1 (IKK $\alpha$ ) and IKK2 (IKK $\beta$ ). This event is followed by IKK2 phosphorylation, which further phosphorylates the NF- $\mathrm{NB}$ inhibitor $\mathrm{I} \kappa \mathrm{B} \alpha$. I $\kappa \mathrm{B} \alpha$ is then ubiquitinated by the $\mathrm{SCF} / \beta-\operatorname{TrCP}$ complex and further degraded by proteasome. The degradation of $\mathrm{I} \kappa \mathrm{B} \alpha$ releases NF- $\mathrm{K} B$ dimers to translocate into the nucleus, where they up-regulate target genes involved in host defense and apoptosis. NOD oligomerization and further RIP2 activation also recruits TAB/TAK1 complexes to mediate the phosphorylation of MAPKs, such as JNK, ERK and p38 MAPK, through the upstream activation of MKKs. These kinases translocate to the nucleus and then phosphorylate AP-1 transcription factors (c-fos, c-Jun, ATF and JDP family members) to mediate the expression of target genes containing a TRE (TPA DNA-response element).

The surface of the intestinal epithelium represents a chemical barrier composed of mucus and AMPs, which are provided by a single layer of intestinal epithelial cells (IECs), Paneth cells, and goblet cells. It has been demonstrated that SCFAs improve both elements of the intestinal barrier. Operating across the short chain fatty acid receptor (GPR43), butyrate brings about the production of AMPs such as Regenerative islet-derived protein III $\gamma(\operatorname{RegIII} \gamma)$ and defensin in IEC [129]. RegIII $\gamma$ is a type of lectin C; it is one of several antimicrobial peptides produced by Paneth cells. Other studies have demonstrated a synergistic mechanism between mucus and the SCFAs caused by AMPs. Butyrate not only influences the yield of cathelicidin but can also improve mucin formation leading to an optimum immunological reaction as opposed to the occurrence of amebic colitis [130]. The induction of $\beta$-defensins by butyrate is Muc2-independent, because the presence of mucus inhibits the antibacterial action of $\beta$-defensin. In fact, the protein encoded by Muc-2 (mucin 2, oligomeric mucus/gel-forming) is secreted and forms an insoluble mucous barrier that protects the gut lumen. Additional research is necessary to highlight the association of mucus with AMPs in relation to SCFAs [131]. 


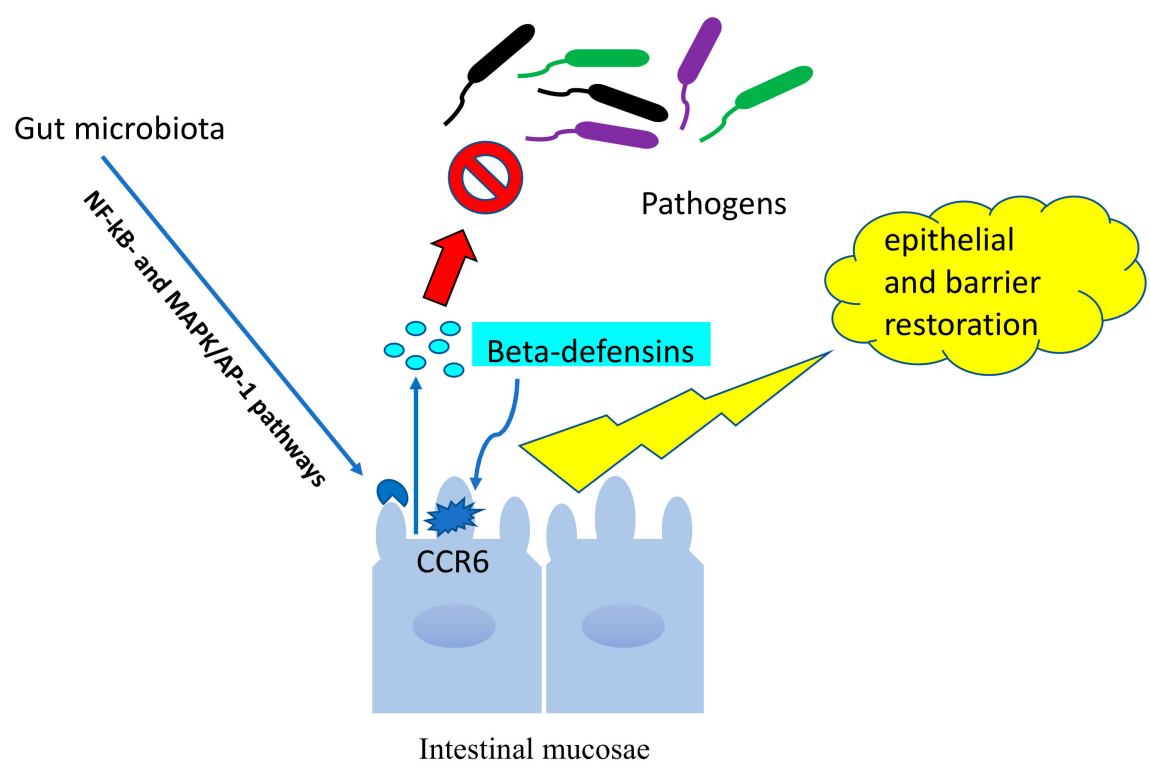

Figure 5. Gut microbiota and induction of human beta-defensins. Gut microbiota secretion via. The NF-kB and MAPK/AP-1 pathways. Beta-defensins interact with CCR6 to restore the epithelium and a barrier.

The gut microbiota can regulate the production of defensins that rapidly kill or deactivate microorganisms [132]. Evidence shows that, in host protection, defensins collaborate with various mediators, such as cytokines, chemokines, supplements, and more antimicrobial proteins, as well as cellular elements, to produce coordinate protection against invading pathogens [133].

\section{Conclusions}

$H p$ has a powerful impact on both the stomach habitat and the immune status of the host, leading to alterations in the gastrointestinal microbiome at disparate sites in the organism. These changes are greatly implicated in the pathogenicity of $\mathrm{Hp}$-associated diseases. AMPs are meaningfully involved in the preservation of the solidity and equilibrium of the gastrointestinal tract. Knowledge of microbial-dependent or -independent factors that influence the expression of AMPs is essential and could lead to new therapeutic approaches to diseases of the gastrointestinal tract (GI) correlated with pathogenic colonization and disequilibrium of the host microbiota. Thus, knowledge of the mechanisms involved in these processes, as well as the $\mathrm{Hp}$-induced microbiome changes that may be connected to the progress of illness, will probably be helpful in predicting and avoiding $\mathrm{Hp}$-related diseases. After forming a mechanistic understanding of animal models, reports on the microbiome will open up a new area of study for the clinical government.

Author Contributions: R.P. and O.S. conceived the article and discussed the complete assembly of data acquisition. R.P. and O.S. wrote the manuscript with S.L., M.-G.D.B. and B.L., M.B. and R.P. revisioned the entire manuscript.

Funding: This research received no external funding.

Acknowledgments: We wish to immensely thank the editor Angela Toribio, for her great availability to guide us meticulously through every step of the publication of our work.

Conflicts of Interest: The authors declare no conflict of interest.

\section{References}

1. De Martel, C.; Ferlay, J.; Franceschi, S.; Vignat, J.; Bray, F.; Forman, D.; Plummer, M. Global burden of cancers attributable to infections in 2008: A review and synthetic analysis. Lancet Oncol. 2012, 13, 607-615. [CrossRef]

2. Suerbaum, S.; Michetti, P. Helicobacter pylori infection. N. Engl. J. Med. 2002, 347, 1175-1186. [CrossRef] [PubMed] 
3. Shmuely, H.; Wattad, M.; Solodky, A.; Yahav, J.; Samra, Z.; Zafrir, N. Association of Helicobacter pylori with coronary artery disease and myocardial infarction assessed by myocardial perfusion imaging. Isr. Med. Assoc. J. 2014, 16, 341-346.

4. Niwa, T.; Toyoda, T.; Tsukamoto, T.; Mori, A.; Tatematsu, M.; Ushijima, T. Prevention of induced gastric cancers in gerbils by a DNA demethylating agent. Cancer Prev. Res. 2013, 6, 263-270. [CrossRef] [PubMed]

5. Andersson, A.F.; Lindberg, M.; Jakobsson, H.; Bäc0ed, F.; Nyrén, P.; Engstrand, L. Comparative analysis of human gut microbiota by barcoded pyrosequencing. PLoS ONE 2008, 3, e2836. [CrossRef] [PubMed]

6. Das, A.; Pereira, V.; Saxena, S.; Ghosh, T.S.; Anbumani, D.; Bag, S.; Das, B.; Nair, G.B.; Abraham, P.; Mande, S.S. Gastric microbiome of Indian patients with Helicobacter pylori infection, and their interaction networks. Sci. Rep. 2017, 7, 15438. [CrossRef] [PubMed]

7. Kienesberger, S.; Cox, L.M.; Livanos, A.; Zhang, X.S.; Chung, J.; Perez-Perez, G.I.; Gorkiewicz, G.; Zechner, E.L.; Blaser, M.J. Gastric Helicobacter pylori infection affects local and distant microbial Populations and host responses. Cell Rep. 2016, 14, 1395-1407. [CrossRef]

8. Coretti, L.; Natale, A.; Cuomo, M.; Florio, E.; Keller, S.; Lembo, F.; Chiariotti, L.; Pero, R. The interplay between defensins and microbiota in Crohn's Disease. Mediat. Inflamm. 2017, 2017, 8392523. [CrossRef]

9. Raymond, J.; Thiberge, J.-M.; Kalach, N.; Bergeret, M.; Dupont, C.; Labigne, A.; Dauga, C. Using macro-arrays to study routes of infection of Helicobacter pylori in three families. PLoS ONE 2008, 3, e2259. [CrossRef]

10. Sgouras, D.N.; Trang, T.T.H.; Yamaoka, Y. Pathogenesis of Helicobacter pylori infection. Helicobacter 2015, 20, 8-16. [CrossRef]

11. Correa, P. A human model of gastric carcinogenesis. Cancer Res. 1988, 48, 3554-3560. [PubMed]

12. Correa, P. Human gastric carcinogenesis: A multistep and multifactorial process-first American Cancer society award lecture on cancer Epidemiology and prevention. Cancer Res. 1992, 52, 6735-6740. [PubMed]

13. Chiariotti, L.; Angrisano, T.; Keller, S.; Florio, E.; Affinito, O.; Pallante, P.; Perrino, C.; Pero, R.; Lembo, F. Epigenetic modifications induced by Helicobacter pylori infection through a direct microbe-gastric epithelial cells cross-talk. Med. Microbiol. Immunol. 2013, 5, 327-337. [CrossRef] [PubMed]

14. Chiariotti, L.; Coretti, L.; Pero, R.; Lembo, F. Epigenetic alterations Induced by bacterial lipopolysaccharides. Adv. Exp. Med. Biol. 2016, 879, 91-105. [PubMed]

15. Angrisano, T.; Pero, R.; Brancaccio, M.; Coretti, L.; Florio, E.; Pezone, A.; Calabrò, V.; Falco, G.; Keller, S.; Lembo, F.; et al. Cyclical DNA methylation and histone changes are induced by LPS to activate COX-2 in human Intestinal epithelial cells. PLoS ONE 2016, 6, e0156671. [CrossRef] [PubMed]

16. Blaser, M.J.; Atherton, J.C. Helicobacter pylori persistence: Biology and disease. J. Clin. Invest. 2004, 3, 321-333. [CrossRef] [PubMed]

17. Peleteiro, B.; Bastos, A.; Ferro, A.; Lunet, N. Prevalence of Helicobacter pylori infection worldwide: A systematic review of studies with national coverage. Dig. Dis. Sci. 2014, 8, 1698-1709. [CrossRef] [PubMed]

18. Mowat, C.; Williams, C.; Gillen, D.; Hossack, M.; Gilmour, D.; Graswell, A.; Wirz, A.; Preston, T.; $\mathrm{McCol}$, K.E.L. Omeprazole, Helicobacter pylori status, and alterations in the intragastric milieu facilitating bacterial N-nitrosation. Gastroenterol 2000, 2, 339e47. [CrossRef]

19. Wang, L.; Zhou, J.; Xin, Y.; Geng, C.; Tian, Z.; Yu, X.; Dong, Q. Bacterial overgrowth and diversification of microbiota in gastric cancer. Eur. J. Gastroenterol. Hepatol. 2016, 28, 261. [CrossRef] [PubMed]

20. Ferreira, R.M.; Pereira-Marques, J.; Pinto-Ribeiro, I.; Costa, J.L.; Carneiro, F.; Machado, J.C.; Figueiredo, C. Gastric microbial community profiling reveals a dysbiotic cancer associated microbiota. Gut 2018, 67, 226-236. [CrossRef] [PubMed]

21. Yang, I.; Woltemate, S.; Piazuelo, M.B.; Bravo, L.E.; Yepez, M.C.; Romero-Gallo, J.; Delgado, A.G.; Wilson, K.T.; Peek, R.M.; Correa, P.; et al. Different gastric microbiota compositions in two human populations with high and low gastric cancer risk in Colombia. Sci. Rep. 2016, 6, 185-194. [CrossRef] [PubMed]

22. Lederberg, J. 'Ome Sweet' omics-A genealogical Treasury of words. Scientist 2001, 15, 8.

23. Moustafa, A.; Xie, C.; Kirkness, E.; Biggs, W.; Wong, E.; Turpaz, Y.; Bloom, K.; Delwart, E.; Nelson, K.E.; Venter, J.C.; et al. The blood DNA virome in 8000 humans. PLoS Pathog. 2017, 13, e1006292.

24. Sender, R.; Fuchs, S.; Milo, R. Revised estimates for the number of human and bacteria cells in the body. PLoS Biol. 2016, 14, e1002533. [CrossRef] [PubMed]

25. Garud, N.R.; Good, B.H.; Hallatschek, O.; Pollard, K.S. Evolutionary dynamics of bacteria in the gut microbiome within and across hosts. PLoS Biol. 2019, 23, e3000102. [CrossRef] [PubMed] 
26. Sekirov, I.; Russell, S.L.; Antunes, L.C.M.; Finlay, B.B. Gut microbiota in health and disease. Physiol. Rev. 2010, 90, 859-904. [CrossRef] [PubMed]

27. Sommer, F.; Bäckhed, F. The gut microbiota-masters of host development and physiology. Nat. Rev. Microbiol. 2013, 11, 227-238. [CrossRef] [PubMed]

28. Dieterich, W.; Schuppan, D.; Schink, M.; Schwappacher, R.; Wirtz, S.; Agaimy, A.; Neurath, M.F.; Zopf, Y. Influence of low FODMAP and gluten-free diets on disease activity and intestinal microbiota in patients with non-celiac gluten sensitivity. Clin. Nutr. 2018, 14, 4. [CrossRef]

29. Juge, N. Microbial adhesins to gastrointestinal mucus. Trends Microbiol. 2012, 20, 30-39. [CrossRef]

30. Forbes, J.D.; Van Domselaar, G.; Bernstein, C.N. The gut microbiota in immune-mediated inflammatory diseases. Front. Microbiol. 2016, 7, 1081. [CrossRef]

31. Jo, H.J.; Kim, J.; Kim, N.; Park, J.H.; Nam, R.H.; Seok, Y.J.; Kim, Y.R.; Kim, J.S.; Kim, J.M.; Kim, J.M.; et al. Analysis of gastric microbiota by pyrosequencing: Minor role of bacteria other than Helicobacter pylori in the gastric carcinogenesis. Helicobacter 2016, 5, 364-374. [CrossRef] [PubMed]

32. Engstrand, L.; Lindberg, M. Helicobacter pylori and the gastric microbiota. Best Pract. Res. Clin. Gastroenterol. 2013, 27, 39-45. [CrossRef]

33. Llorca, L.; Pérez-Pérez, G.; Urruzuno, P.; Martinez, M.J.; Iizumi, T.; Gao, Z.; Sohn, J.; Chung, J.; Cox, L.; Simón-Soro, A.; et al. Characterization of the gastric microbiota in a pediatric population according to Helicobacter pylori Status. Pediatr. Infect. Dis. J. 2017, 36, 173-178. [CrossRef] [PubMed]

34. Monstein, H.J.; Tiveljung, A.; Kraft, C.H.; Borch, K.; Jonasson, J. Profiling of bacterial flora in gastric biopsies from patients with Helicobacter pylori-associated gastritis and histologically normal control individuals by temperature gradient gel electrophoresis and $16 \mathrm{~S}$ rDNA sequence analysis. J. Med. Microbiol. 2000, 49, 817-822. [CrossRef] [PubMed]

35. Bik, E.M.; Eckburg, P.B.; Gill, S.R.; Nelson, K.E.; Purdom, E.A.; Francois, F.; Perez-Perez, G.; Blaser, M.J.; Relman, D.A. Molecular analysis of the bacterial microbiota in the human stomach. Proc. Natl. Acad. Sci. USA 2006, 103, 732-737. [CrossRef]

36. Delgado, S.; Cabrera-Rubio, R.; Mira, A.; Suárez, A.; Mayo, B. Microbiological survey of the human gastric ecosystem using culturing and pyrosequencing methods. Microb. Ecol. 2013, 65, 763-772. [CrossRef]

37. Dicksved, J.; Lindberg, M.; Rosenquist, M.; Enroth, H.; Jansson, J.K.; Engstrand, L. Molecular characterization of the stomach microbiota in patients with gastric cancer and in controls. J. Med. Microbiol. 2009, 58, 509-516. [CrossRef]

38. Li, X.X.; Wong, G.L.; To, K.F.; Wong, V.W.; Lai, L.H.; Chow, D.K.; Lau, J.Y.; Sung, J.J.; Ding, C. Bacterial microbiota profiling in gastritis without Helicobacter pylori infection or non-steroidal anti-inflammatory drug use. PLoS ONE 2009, 4, e7985. [CrossRef]

39. Maldonado-Contreras, A.; Goldfarb, K.C.; Godoy-Vitorino, F.; Karaoz, U.; Contreras, M.; Blaser, M.J.; Brodie, E.L.; Dominguez-Bello, M.G. Structure of the human gastric bacterial community in relation to Helicobacter pylori status. ISME J. 2011, 5, 574-579. [CrossRef]

40. Schulz, C.; Schütte, K.; Koch, N.; Vilchez-Vargas, R.; Wos-Oxley, M.L.; Oxley, A.P.A.; Vital, M.; Malfertheiner, P.; Pieper, D.H. The active bacterial assemblages of the upper GI tract in individuals with and without Helicobacter infection. Gut 2018, 67, 216-225. [CrossRef]

41. Noto, J.M.; Peek, R.M., Jr. The gastric microbiome, its interaction with Helicobacter pylori, and its potential role in the progression to stomach cancer. PLoS Pathog. 2017, 13, e1006573. [CrossRef] [PubMed]

42. Dong, Q.; Xin, Y.; Wang, L.; Meng, X.; Yu, X.; Lu, L.; Xuan, S. Characterization of gastric microbiota in twins. Curr. Microbiol. 2017, 74, 224-229. [CrossRef] [PubMed]

43. Brawner, K.M.; Kumar, R.; Serrano, C.A.; Ptacek, T.; Lefkowitz, E.; Morrow, C.D.; Zhi, D.; Kyanam-Kabir-Baig, K.R.; Smythies, L.E.; Harris, P.R.; et al. Helicobacter pylori infection is associated with an altered gastric microbiota in children. Mucosal Immunol. 2017, 10, 1169-1177. [CrossRef] [PubMed]

44. Bauerfeind, P.; Garner, R.; Dunn, B.E.; Mobley, H.L. Synthesis and activity of Helicobacter pylori urease and catalase at low pH. Gut 1997, 40, 25-30. [CrossRef] [PubMed]

45. Wen, Y.; Feng, J.; Scott, D.R.; Marcus, E.A.; Sachs, G. The HP0165- HP0166 two-component system (ArsRS) regulates acid-induced expression of HP1186 alpha-carbonic anhydrase in Helicobacter pylori by activating the pH-dependent promoter. J. Bacteriol. 2007, 189, 2426-2434. [CrossRef] [PubMed]

46. Williams, C.L.; Preston, T.; Hossack, M.; Slater, C.; McColl, K.E. Helicobacter pylori utilises urea for amino acid synthesis. FEMS Immunol. Med. Microbiol. 1996, 13, 87-94. [CrossRef] 
47. Ziebarth, D.; Spiegelhalder, B.; Bartsch, H. N-nitrosation of medicinal drugs catalysed by bacteria from human saliva and gastro-intestinal tract, including Helicobacter pylori. Carcinogenesis 1997, 18, 383-389. [CrossRef]

48. Parsons, B.N.; Ijaz, U.Z.; D'Amore, R.; Burkitt, M.D.; Eccles, R.; Lenzi, L.; Duckworth, C.A.; Moore, A.R.; Tiszlavicz, L.; Varro, A.; et al. Comparison of the human gastric microbiota in hypochlorhydric states arising as a result of Helicobacter pylori induced atrophic gastritis, autoimmune atrophic gastritis and proton pump inhibitor use. PLoS Pathog. 2017, 13, e1006653. [CrossRef]

49. Hansson, L.E.; Nyrén, O.; Hsing, A.W.; Bergström, R.; Josefsson, S.; Chow, W.H.; Fraumeni, J.F., Jr.; Adami, H.O. The risk of stomach cancer in patients with gastric or duodenal ulcer disease. N. Engl. J. Med. 1996, 335, 242-249. [CrossRef]

50. Uemura, N.; Okamoto, S.; Yamamoto, S.; Matsumura, N.; Yamaguchi, S.; Yamakido, M.; Taniyama, K.; Sasaki, N.; Schlemper, R.J. Helicobacter pylori infection and the development of gastric cancer. N. Engl. J. Med. 2001, 345, 784-789. [CrossRef]

51. Guerre, J.; Vedel, G.; Gaudric, M.; Paul, G.; Cornuau, J. Bacterial flora in gastric juice taken at endoscopy in 93 normal subjects. Pathol. Biol. 1986, 34, 57-60. [PubMed]

52. Espinoza, J.L.; Matsumoto, A.; Tanaka, H.; Matsumura, I. Gastric microbiota: An emerging player in Helicobacter pylori-induced gastric malignancies. Cancer Lett. 2018, 414, 147-152. [CrossRef] [PubMed]

53. Goddard, A.F.; Spiller, R.C. The effect of omeprazole on gastric juice viscosity, $\mathrm{pH}$ and bacterial counts. Aliment. Pharmacol. Ther. 1996, 10, 105-109.

54. Navabi, N.; Raghavan, S.; Lindén, S.K. Helicobacter pylori infection impairs the mucin production rate and turnover in the murine gastric mucosa. Infect. Immun. 2013, 81, 829-837. [CrossRef] [PubMed]

55. Yap, T.W.; Gan, H.M.; Lee, Y.P.; Leow, A.H.; Azmi, A.N.; Francois, F.; Perez-Perez, G.I.; Loke, M.F.; Goh, K.L.; Vadivelu, J. Helicobacter pylori eradication causes perturbation of the human gut microbiome in young adults. PLoS ONE 2016, 11, e0151893.

56. Heimesaat, M.M.; Fischer, A.; Plickert, R.; Wiedemann, T.; Loddenkemper, C.; Göbel, U.B.; Bereswill, S.; Rieder, G. Helicobacter pylori induced gastric immunopathology is associated with distinct microbiota changes in the large intestines of long-term infected mongolian gerbils. PLoS ONE 2014, 9, e100362. [CrossRef]

57. Majlessi, L.; Sayes, F.; Bureau, J.F.; Pawlik, A.; Michel, V.; Jouvion, G.; Huerre, M.; Severgnini, M.; Consolandi, C.; Peano, C.; et al. Colonization with Helicobacter is concomitant with modified gut microbiota and drastic failure of the immune control of Mycobacterium tuberculosis. Mucosal Immunol. 2017, 10, 1178-1189. [CrossRef]

58. Gebert, B.; Fischer, W.; Weiss, E.; Hoffmann, R.; Haas, R. Helicobacter pylori vacuolating cytotoxin inhibits T lymphocyte activation. Science 2003, 301, 1099-1102. [CrossRef]

59. Wüstner, S.; Mejías-Luque, R.; Koch, M.F.; Rath, E.; Vieth, M.; Sieber, S.A.; Haller, D.; Gerhard, M. Helicobacter pylori $\gamma$-glutamyl transpeptidase impairs T-lymphocyte function by compromising metabolic adaption through inhibition of cMyc and IRF4 expression. Cell Microbiol. 2015, 17, 51-61. [CrossRef]

60. Khosravi, Y.; Loke, M.F.; Goh, K.L.; Vadivelu, J. Proteomics analysis revealed that crosstalk between Helicobacter pylori and Streptococcus mitis may enhance bacterial survival and reduces carcinogenesis. Front. Microbiol. 2016, 7, 1462. [CrossRef]

61. Boyanova, L.; Gergova, G.; Markovska, R.; Yordanov, D.; Mitov, I. Bacteriocin-like inhibitory activities of seven Lactobacillus delbrueckii subsp. bulgaricus strains against antibiotic susceptible and resistant Helicobacter pylori strains. Lett. Appl. Microbiol. 2017, 65, 469-474. [CrossRef] [PubMed]

62. Salas-Jara, M.J.; Sanhueza, E.A.; Retamal-Díaz, A.; González, C.; Urrutia, H.; García, A. Probiotic lactobacillus fermentum UCO-979C biofilm formation on AGS and Caco-2 cells and Helicobacter pylori inhibition. Biofouling 2016, 32, 1245-1257. [CrossRef]

63. Zheng, P.X.; Fang, H.Y.; Yang, H.B.; Tien, N.Y.; Wang, M.C.; Wu, J.J. Lactobacillus pentosus strain LPS16 produces lactic acid, inhibiting multidrug-resistant Helicobacter pylori. J. Microbiol. Immunol. Infect. 2016, 49, 168-174. [CrossRef]

64. Hooper, L.V.; Littman, D.R.; Macpherson, A.J. Interactions between the microbiota and the immune system. Science 2012, 336, 1268-1273. [CrossRef] [PubMed]

65. Martin, M.E.; Bhatnagar, S.; George, M.D.; Paster, B.J.; Canfield, D.R.; Eisen, J.A.; Solnick, J.V. The impact of Helicobacter pylori infection on the gastric microbiota of the rhesus macaque. PLoS ONE 2013, 8, e76375. [CrossRef] [PubMed] 
66. Yin, Y.N.; Wang, C.L.; Liu, X.W.; Cui, Y.; Xie, N.; Yu, Q.F.; Li, F.J.; Lu, F.G. Gastric and duodenum microflora analysis after long-term Helicobacter pylori infection in Mongolian gerbils. Helicobacter 2011, 16, 389-397. [CrossRef] [PubMed]

67. Khosravi, Y.; Dieye, Y.; Poh, B. Culturable bacterial microbiota of the stomach of Helicobacter pylori positive and negative gastric disease patients. Sci. World 2014, 2014, 1-10.

68. Hu, Y.; He, L.; Xiao, D.; Liu, G. Bacterial flora concurrent with Helicobacter pylori in the stomach of patients with upper gastrointestinal diseases. World. J. Gastroenterol. 2012, 18, 1257-1261. [CrossRef] [PubMed]

69. Goldsmith, J.R.; Sartor, R.B. The role of diet on intestinal microbiota metabolism: Downstream impacts on host immune function and health, and therapeutic implications. J. Gastroenterol. 2014, 49, 785-798. [CrossRef]

70. David, L.A.; Maurice, C.F.; Carmody, R.N.; Gootenberg, D.B.; Button, J.E.; Wolfe, B.E.; Ling, A.V.; Devlin, A.S.; Varma, Y.; Fischbach, M.A.; et al. Diet rapidly and reproducibly alters the human gut microbiome. Nature 2014, 505, 559-563. [CrossRef]

71. Sanduleanu, S.; Jonkers, D.; De Bruine, A.; Hameeteman, W.; Stockbrügger, R.W. Non-Helicobacter pylori bacterial flora during acid-suppressive therapy: Differential findings in gastric juice and gastric mucosa. Aliment. Pharmacol. Ther. 2001, 15, 379-388. [CrossRef] [PubMed]

72. Lombardo, B.; Izzo, V.; Terracciano, D.; Ranieri, A.; Mazzaccara, C.; Fimiani, F.; Cesaro, A.; Gentile, L.; Leggiero, E.; Pero, R.; et al. Laboratory medicine: Health evaluation in elite athletes. Clin. Chem. Lab. Med. 2019, 5. [CrossRef] [PubMed]

73. De Filippo, C.; Cavalieri, D.; Di Paola, M.; Ramazzotti, M.; Poullet, J.B.; Massart, S.; Collini, S.; Pieraccini, G.; Lionetti, P. Impact of diet in shaping gut microbiota revealed by a comparative study in children from Europe and rural Africa. Proc. Natl. Acad. Sci. USA 2010, 107, 14691-14696. [CrossRef] [PubMed]

74. Cotillard, A.; Kennedy, S.P.; Kong, L.C.; Prifti, E.; Pons, N.; Le Chatelier, E.; Almeida, M.; Quinquis, B.; Levenez, F.; Galleron, N.; et al. Dietary intervention impact on gut microbial gene richness. Nature 2013, 500, 585-588. [CrossRef] [PubMed]

75. Moschen, A.R.; Wieser, V.; Tilg, H. Dietary factors major regulators of the gut's microbiota. Gut Liver 2012, 6, 411-416. [CrossRef]

76. Devkota, S.; Wang, Y.; Musch, M.W.; Leone, V.; Fehlner-Peach, H.; Nadimpalli, A.; Antonopoulos, D.A.; Jabri, B.; Chang, E.B. Dietary-fat-induced taurocholic acid promotes pathobiont expansion and colitis in Il10 -/- mice. Nature 2012, 487, 104-108. [CrossRef] [PubMed]

77. Feng, Q.; Liang, S.; Jia, H.; Stadlmayr, A.; Tang, L.; Lan, Z.; Zhang, D.; Xia, H.; Xu, X.; Jie, Z.; et al. Gut microbiome development along the colorectal adenoma-carcinoma sequence. Nat. Commun. 2015, 6, 6528. [CrossRef]

78. Imhann, F.; Vich Vila, A.; Bonder, M.J.; Lopez Manosalva, A.G.; Koonen, D.P.Y.; Fu, J.; Wijmenga, C.; Zhernakova, A.; Weersma, R.K. The influence of proton pump inhibitors and other commonly used medication on the gut microbiota. Gut Microbes 2017, 4, 351-358. [CrossRef]

79. Pérez-Cobas, A.E.; Artacho, A.; Knecht, H.; Ferrús, M.L.; Friedrichs, A.; Ott, S.J.; Moya, A.; Latorre, A.; Gosalbes, M.J. Differential effects of antibiotic therapy on the structure and function of human gut microbiota. PLoS ONE 2013, 8, e80201. [CrossRef]

80. Iizumi, T.; Battaglia, T.; Ruiz, V.; Perez, G.I. Gut microbiome and antibiotics. Arch. Med. Res. 2017, 48, 727-734. [CrossRef]

81. Tidjani Alou, M.; Lagier, J.C.; Raoult, D. Diet influence on the gut microbiota and dysbiosis related to nutritional disorders. Hum. Microbiome J. 2016, 1, 3-11. [CrossRef]

82. Yatsunenko, T.; Rey, F.E.; Manary, M.J.; Trehan, I.; Dominguez-Bello, M.G.; Contreras, M.; Magris, M.; Hidalgo, G.; Baldassano, R.N.; Anokhin, A.P.; et al. Human gut microbiome viewed across age and geography. Nature 2012, 486, 222-227. [CrossRef]

83. Bai, J.; Hu, Y.; Bruner, D.W. Composition of gut microbiota and its association with body mass index and lifestyle factors in a cohort of 7-18 years old children from the American gut project. Pediatr. Obes. 2019, 14, e12480. [CrossRef] [PubMed]

84. Monda, V.; Villano, I.; Messina, A.; Valenzano, A.; Esposito, T.; Moscatelli, F.; Viggiano, A.; Cibelli, G.; Chieffi, S.; Monda, M.; et al. Exercise modifies the gut microbiota with positive health effects. Oxid. Med. Cell. Longev. 2017, 2017, 3831972. [CrossRef] [PubMed] 
85. Clarke, S.F.; Murphy, E.F.; O’Sullivan, O.; Lucey, A.J.; Humphreys, M.; Hogan, A.; Hayes, P.; O’Reilly, M.; Jeffery, I.B.; Wood-Martin, R.; et al. Exercise and associated dietary extremes impact on gut microbial diversity. Gut 2014, 63, 1913-1920. [CrossRef] [PubMed]

86. Goodrich, J.K.; Waters, J.L.; Poole, A.C.; Sutter, J.L.; Koren, O.; Blekhman, R.; Beaumont, M.; Van Treuren, W.; Knight, R.; Bell, J.T.; et al. Human genetics shape the gut microbiome. Cell 2014, 4, 789-799. [CrossRef]

87. Richards, A.L.; Burns, M.B.; Alazizi, A.; Barreiro, L.B.; Pique-Regi, R.; Blekhman, R.; Luca, F. Genetic and transcriptional analysis of human host response to healthy gut microbiota. Msystems 2016, 4, e00067-16. [CrossRef]

88. Turpin, W.; Espin-Garcia, O.; Xu, W.; Silverberg, M.S.; Kevans, D.; Smith, M.I.; Guttman, D.S.; Griffiths, A.; Panaccione, R.; Otley, A.; et al. Association of host genome with intestinal microbial composition in a large healthy cohort. Nat. Genet. 2016, 11, 1413-1417. [CrossRef]

89. Wacklin, P.M.; Mäkivuokko, H.; Alakulppi, N.; Nikkilä, J.; Tenkanen, H.; Räbinä, J.; Partanen, J.; Aranko, K.; Mättö, J. Secretor genotype (FUT2 gene) is strongly associated with the composition of Bifidobacteria in the human intestine. PLoS ONE 2011, 6, e20113. [CrossRef]

90. Capitani, N.; Codolo, G.; Vallese, F.; Minervini, G.; Grassi, A.; Cianchi, F.; Troilo, A.; Fischer, W.; Zanotti, G.; Baldari, C.T.; et al. The lipoprotein HP1454 of Helicobacter pylori regulates T-cell response by shaping T-cell receptor signalling. Cell Microbiol. 2019, 5, e13006. [CrossRef]

91. Rothschild, D.; Weissbrod, O.; Barkan, E.; Kurilshikov, A.; Korem, T.; Zeevi, D.; Costea, P.I.; Godneva, A.; Kalka, I.N.; Bar, N.; et al. Environment dominates over host genetics in shaping human gut microbiota. Nature 2018, 555, 210-215. [CrossRef] [PubMed]

92. Selsted, M.E.; Ouellette, A.J. Mammalian defensins in the antimicrobial immune response. Nat. Immunol. 2005, 6, 551-557. [CrossRef] [PubMed]

93. Wilson, C.L.; Ouellette, A.J.; Satchell, D.P.; Ayabe, T.; Lopez-Boado, Y.S.; Stratman, J.L.; Hultgren, S.J.; Matrisian, L.M.; Parks, W.C. Regulation of intestinal alpha-defensin activation by the metalloproteinase matrilysin in innate host defense. Science 1999, 286, 113-117. [CrossRef] [PubMed]

94. Nigro, E.; Colavita, I.; Sarnataro, D.; Scudiero, O.; Zambrano, G.; Granata, V.; Daniele, A.; Carotenuto, A.; Galdiero, S.; Folliero, V.; et al. An ancestral host defence peptide within human $\beta$-defensin 3 recapitulates the antibacterial and antiviral activity of the full-length molecule. Sci. Rep. 2015, 5, 18450. [CrossRef] [PubMed]

95. Ganz, T. Antimicrobial polypeptides. J. Leukoc. Biol. 2004, 75, 34-38. [CrossRef] [PubMed]

96. O'Neil, D.A.; Porter, E.M.; Elewaut, D.; Anderson, G.M.; Eckmann, L.; Ganz, T.; Kagnoff, M.F. Expression and regulation of the human $\beta$-defensins hBD-1 and hBD-2 in intestinal epithelium. J. Immunol. 1999, 163, 6718-6724. [PubMed]

97. Ganz, T. Defensins: Antimicrobial peptides of innate immunity. Nat. Rev. Immunol. 2003, 3, 710-720. [CrossRef]

98. Hill, C.P.; Yee, J.; Selsted, M.E.; Eisenberg, D. Crystal structure of defensin HNP-3, an amphiphilic dimer: Mechanisms of membrane permeabilization. Science 1991, 251, 1481-1485. [CrossRef] [PubMed]

99. Szyk, A.; Wu, Z.; Tucker, K.; Yang, D.; Lu, W.; Lubkowski, J. Crystal structures of human alpha-defensins HNP4, HD5, and HD6. Protein Sci. 2006, 15, 2749-2760. [CrossRef] [PubMed]

100. Madison, M.N.; Kleshchenko, Y.Y.; Nde, P.N.; Simmons, K.J.; Lima, M.F.; Villalta, F. Human defensin alpha-1 causes trypanosoma cruzi membrane pore formation and induces DNA fragmentation, which leads to trypanosome destruction. Infect. Immun. 2007, 75, 4780-4791. [CrossRef] [PubMed]

101. Brogden, K.A. Antimicrobial peptides: Pore formers or metabolic inhibitors in bacteria? Nat. Rev. Microbiol. 2005, 3, 238-250. [CrossRef] [PubMed]

102. Schroeder, B.O.; Ehmann, D.; Precht, J.C.; Castillo, P.A.; Küchler, R.; Berger, J.; Schaller, M.; Stange, E.F.; Wehkamp, J. Paneth cella-defensin6 (HD-6) is an antimicrobial peptide. Mucosal Immunol. 2014, 1, 1-11.

103. Van Es, J.H.; Jay, P.; Gregorieff, A.; van Gijn, M.E.; Jonkheer, S.; Hatzis, P.; Thiele, A.; van den Born, M.; Begthel, H.; Brabletz, T.; et al. Wnt signal-ling induces maturation of paneth cells in intestinal crypts. Nat. Cell Biol. 2005, 7, 381-386. [CrossRef] [PubMed]

104. Lichtenstein, A.; Ganz, T.; Selsted, M.E.; Lehrer, R.I. In vitro tumor cell cytolysis mediated by peptide defensins of human and rabbit granulocytes. Blood 1986, 68, 1407-1410. [PubMed]

105. Ghosh, D.; Porter, E.; Shen, B.; Lee, S.K.; Wilk, D.; Drazba, J.; Yadav, S.P.; Crabb, J.W.; Ganz, T.; Bevins, C.L. Paneth cell trypsinis the processing enzyme for human defensin-5. Nat. Immunol. 2002, 3, 583-590. [CrossRef] [PubMed] 
106. Meyer-Hoffert, U.; Hornef, M.W.; Henriques-Normark, B.; Axelsson, L.G.; Midtvedt, T.; Pütsep, K.; Andersson, M. Secreted enteric antimicrobial activity localises to the mucus surface layer. Gut 2008, 57, 764-771. [CrossRef] [PubMed]

107. Peyrin-Biroulet, L.; Beisner, J.; Wang, G.; Nuding, S.; Oommen, S.T.; Kelly, D.; Parmentier-Decrucq, E.; Dessein, R.; Merour, E.; Chavatte, P.; et al. Peroxisome proliferator-activated receptor gamma activation is required for maintenance of innate antimicrobial immunity in the colon. Proc. Natl. Acad. Sci. USA 2010, 19, 8772-8777. [CrossRef]

108. Schupp, M.; Lazar, M.A. Endogenous ligands for nuclear receptors: Digging deeper. J. Biol. Chem. 2010, 285, 40409-40415. [CrossRef]

109. Bensinger, S.J.; Tontonoz, P. Integration of metabolism and inflammation by lipid-activated nuclear receptors. Nature 2008, 454, 470-477. [CrossRef]

110. Simeoli, R.; Mattace Raso, G.; Lama, A.; Pirozzi, C.; Santoro, A.; Di Guida, F.; Sanges, M.; Aksoy, E.; Calignano, A.; D'Arienzo, A.; et al. Preventive and therapeutic effects of Lactobacillus paracasei B21060-basedsynbiotic treatment on gut inflammation and barrier integrity in colitic mice. J. Nutr. 2015, 145, 1202-1210. [CrossRef]

111. Robinson, K.; Argent, R.H.; Atherton, J.C. The inflammatory and immune response to Helicobacter pylori infection. Best Pract. Res. Clin. Gastroenterol. 2007, 2, 237-259. [CrossRef] [PubMed]

112. Wehkamp, J.; Schmidt, K.; Herrlinger, K.R.; Baxmann, S.; Behling, S.; Wohlschläger, C.; Feller, A.C.; Stange, E.F.; Fellermann, K. Defensin pattern in chronic gastritis: HBD-2 is differentially expressed with respect to helicobacter Hp status. J. Clin. Pathol. 2003, 55, 352-357. [CrossRef]

113. Grubman, A.; Kaparakis, M.; Viala, J.; Allison, C.; Badea, L.; Karrar, A.; Boneca, I.G.; Le Bourhis, L.; Reeve, S.; Smith, I.A.; et al. The innate immune molecule, NOD1, regulates direct killing of Helicobacter pylori by antimicrobial peptides. Cell. Microbiol. 2010, 12, 626-639. [CrossRef] [PubMed]

114. Bajaj-Elliott, M.; Fedeli, P.; Smith, G.V.; Domizio, P.; Maher, L.; Ali, R.S.; Quinn, A.G.; Farthing, M.J.G. Modulation of host antimicrobial peptide ( $\beta$-defensins 1 and 2 ) expression during gastritis. Gut 2002, 53, 356-361. [CrossRef] [PubMed]

115. Hamanaka, Y.; Nakashima, M.; Wada, A.; Ito, M.; Kurazono, H.; Hojo, H.; Nakahara, Y.; Kohno, S.; Hirayama, T.; Sekine, I. Expression of human $\beta$-defensin 2 (hBD-2) in Helicobacter pylori induced gastritis: Antibacterial effect of hBD-2 against Helicobacter pylori. Gut 2001, 4, 481-487. [CrossRef]

116. Kawauchi, K.; Yagihashi, A.; Tsuji, N.; Uehara, N.; Furuya, D.; Kobayashi, D.; Watanabe, N. Human $\beta$-defensin-3 induction in $\mathrm{Hp}$-infected gastric mucosal tissues. World J. Gastroenterol. 2006, 12, 5793-5797. [CrossRef]

117. Otte, J.M.; Neumann, H.M.; Brand, S.; Schrader, H.; Schmidt, W.E.; Schmitz, F. Expression of $\beta$-defensin 4 is increased in human gastritis. Eur. J. Clin. Invest. 2009, 2, 126-138. [CrossRef]

118. Taha, A.S.; Faccenda, E.; Angerson, W.J.; Balsitis, M.; Kelly, R.W. Gastric epithelial anti-microbial peptides-histological correlation and influence of anatomical site and peptic ulcer disease. Dig. Liver Dis. 2005, 37, 51-56. [CrossRef]

119. Gruenheid, S.; Le Moual, H. Resistance to antimicrobial peptides in gram-negative bacteria. FEMS Microbiol. Lett. 2012, 2, 81-89. [CrossRef]

120. Koprivnjak, T.; Peschel, A. Bacterial resistance mechanisms against host defense peptides. Cell Mol. Life Sci. 2011, 13, 2243-2254. [CrossRef]

121. McGee, D.J.; George, A.E.; Trainor, E.A.; Horton, K.E.; Hildebrandt, E.; Testerman, T.L. Cholesterol enhances Helicobacter pylori resistance to antibiotics and LL-37. Antimicrob. Agents Chemother. 2011, 6, 2897-2904. [CrossRef] [PubMed]

122. Bauer, B.; Wex, T.; Kuester, D.; Meyer, T.; Malfertheiner, P. Differential expression of human beta defensin 2 and 3 in gastric mucosa of helicobacter pylori-infected individuals. Helicobacter 2013, 1, 6-12. [CrossRef] [PubMed]

123. Boman, H.G. Antibacterial peptides: Basic facts and emerging concepts. J. Intern. Med. 2003, 3, 197-215. [CrossRef]

124. Wehkamp, J.; Harder, J.; Wehkamp, K.; Wehkamp-von Meissner, B.; Schlee, M.; Enders, C.; Sonnenborn, U.; Nuding, S.; Bengmark, S.; Fellermann, K.; et al. NF-kappa B- and AP-1-mediated induction of human beta defensin-2 in intestinal epithelial cells by Escherichia coli nissle 1917: A novel effect of a probiotic bacterium. Infect. Immun. 2004, 10, 5750-5758. [CrossRef] [PubMed] 
125. Schlee, M.; Wehkamp, J.; Altenhoefer, A.; Oelschlaeger, T.A.; Stange, E.F.; Fellermann, K. Induction of human beta-defensin 2 by the probiotic Escherichia coli nissle 1917 is mediated through flagellin. Infect. Immun. 2007, 75, 2399-2407. [CrossRef]

126. Steubesand, N.; Kiehne, K.; Brunke, G.; Pahl, R.; Reiss, K.; Herzig, K.H.; Schubert, S.; Schreiber, S.; Fölsch, U.R.; Rosenstiel, P.; et al. The expression of the beta-defensins hBD-2 and hBD-3 is differentially regulated by NF-kappaB and MAPK/AP-1 pathways in an in vitro model of Candida esophagitis. BMC Immunol. 2009, 10, 36. [CrossRef] [PubMed]

127. Seo, E.J.; Weibel, S.; Wehkamp, J.; Oelschlaeger, T.A. Construction of recombinant E. coli nissle 1917 (EcN) strains for the expression and secretion of defensins. Int. J. Med. Microbiol. 2012, 302, 276-287. [CrossRef]

128. Wada, A.; Mori, N.; Oishi, K.; Hojo, H.; Nakahara, Y.; Hamanaka, Y.; Nagashima, M.; Sekine, I.; Ogushi, K.; Niidome, T.; et al. Induction of human beta-defensin-2 mRNA expression by Helicobacter pylori in human gastric cell line MKN45 cells on cag pathogenicity island. Biochem. Biophys. Res. Commun. 1999, 263, 770-774. [CrossRef]

129. Zhao, Y.; Chen, F.; Wu, W.; Sun, M.; Bilotta, A.J.; Yao, S.; Xiao, Y.; Huang, X.; Eaves-Pyles, T.D.; Golovko, G.; et al. GPR43 mediates microbiota metabolite SCFA regulation of antimicrobial peptide expression in intestinal epithelial cells via activation of mTOR and STAT3. Mucosal Immunol. 2018, 11, 752-762. [CrossRef]

130. Cobo, E.R.; Kissoon-Singh, V.; Moreau, F.; Holani, R.; Chadee, K. MUC2 mucin and butyrate contribute to the synthesis of the antimicrobial peptide cathelicidin in response to entamoeba histolytica-and dextran sodium sulfate-induced colitis. Infect. Immun. 2017, 85, e00905-16. [CrossRef]

131. Cobo, E.R.; Kissoon-Singh, V.; Moreau, F.; Chadee, K. Colonic MUC2 mucin regulates the expression and antimicrobial activity of beta-defensin 2. Mucosal Immunol. 2015, 8, 1360-1372. [CrossRef] [PubMed]

132. Dolara, P.; Luceri, C.; De Filippo, C.; Pietro Femia, A.; Giovannelli, L.; Caderni, G.; Cecchini, C.; Silvi, S.; Orpianesi, C.; Cresci, A. Red wine polyphenols influence carcinogenesis, intestinal microflora, oxidative damage and gene expression profiles of colonic mucosa in F344 rats. Mutat. Res. Fundam. Mol. Mech. Mutagen. 2005, 591, 237-246. [CrossRef] [PubMed]

133. Yang, D.; Chertov, O.; Oppenheim, J.J. Participation of mammalian defensins and cathelicidins in anti-microbial immunity: Receptors and activities of human defensins and cathelicidin (LL-37). J. Leukoc. Biol. 2001, 69, 691-697. [PubMed] 